\title{
Dlaczego inteligent nie chce być homo politicus? Melancholia jako kategoria interpretująca prozę rozrachunków inteligenckich (1946-1948)
}

\author{
Why the intellectual doesn't want to be homo politicus? \\ Melancholy as the interpretative key used to analyse \\ literature of retribution (1946-1948)
}

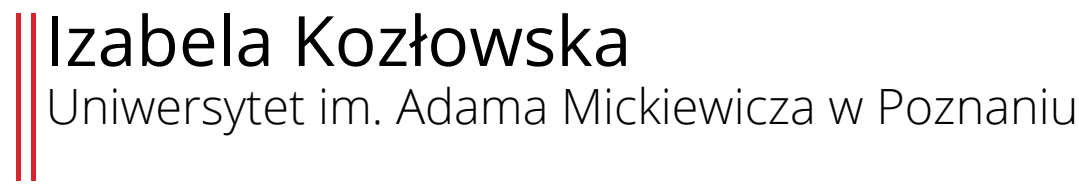

\begin{abstract}
The subject of the article is literature of retribution written between the years 1946-1948. The post-war literary criticism accused the characters - the intellectuals of passivity, self-centeredness and reserve towards contemporary socio-political transformations. The only issue seen by the critics was the attempt to establish the role of the Intelligentsia in the time of a historic breakthrough. With the use of the melancholic perspective I showed a new dimension of the intellectuals' passivity and I have proven that the outer immobility does not have to go with the inner stagnation. The characters' torpor became a condition necessary for their intellectual and emotional activity, which manifested itself through a conscious gesture of resistance against the soulless machinery of History, which threatened an individual.
\end{abstract}

Key words: literature of retribution, the intellectual, melancholy, the post-war literary criticism, history

Streszczenie: Tematem artykułu jest proza rozrachunków inteligenckich, powstająca w latach 1946-1948. Powojenna krytyka literacka zarzucała bohaterom - inteligentom bierność, egocentryzm i rezerwę wobec współczesnych przemian społeczno-politycznych. Dostrzegała w powieściach jedynie próbę określenia roli inteligencji w warunkach historycznego przełomu. Za pomocą melancholijnej perspektywy pokazałam nowy wymiar bierności omawianych inteligentów - udowodniłam, że zewnętrzna nieruchomość nie musi być tożsama z wewnętrzną stagnacją. Marazm bohaterów stał się koniecznym warunkiem ich intelektualnej i emocjonalnej aktywności, przejawiającej się w świadomym geście oporu przeciw zagrażającej jednostce, bezdusznej machinie Historii.

Słowa kluczowe: literatura rozrachunkowa, inteligent, melancholia, powojenna krytyka literacka, historia

\section{Wprowadzenie}

Kazimierz Wyka wyodrębnił w 1948 roku w polskiej literaturze powojennej nurt „rozrachunków inteligenckich” i zaliczył do niego: Drewnianego konia (1946) Kazimierza Brandysa, Jezioro Bodeńskie (1946) Stanisława 
Dygata, Sedan (1946) Pawła Hertza oraz Sprzysiężenie (1947) Stefana Kisielewskiego (Wyka 1989, 181-199) ${ }^{1}$. Krytycy literaccy z lat 40. wykorzystywali do analizy wymienionych tekstów ideologię marksistowską, co sprawiało, że zarzucali bohaterom bierność i rezerwę wobec przemian społeczno-politycznych zachodzących w Polsce (Sobolewska 1979, 37). Kontekst polityczny nie wyjaśnia jednak złożoności zarówno problematyki filozoficznej, jak i historycznej utworów (Zaworska 1965). Szersze spojrzenie na tematykę dzieł oraz rehabilitacja sportretowanych w nich inteligentów są możliwe przy użyciu figury melancholii. Wyróżnione przez Wykę powieści warto traktować jako literature melancholijną, a bohaterów określić jako dzieci Saturna ${ }^{2}$. Melancholia jest w ich przypadku kategorią filozoficzną, egzystencjalną czy psychologiczną, ale także stanowiskiem politycznym zajętym wobec II wojny światowej i przejęcia w Polsce w 1945 roku władzy przez komunistów ${ }^{3}$.

\section{Ucieczka melancholików z Historii}

\section{Paradygmat heglowsko-marksistowski}

Marek Bieńczyk definiuje melancholię jako „postawę myślową, którą konstytuuje szczególny stosunek do dziejów jako procesu w czasie" (Bieńczyk 2002, 20). Stanowisko wobec Historii jest równie ważnym jej wyróżnikiem co takie atrybuty, jak: smutek, rozpacz, depresja, nieobecność, tęsknota, ironia czy autoagresja. Melancholik pozostaje z nią w relacji bliskości i dystansu, jest dla niego jednocześnie źródłem rozpaczy i siły.

Günter Grass w szkicu poświęconym rycinie Melancholia I (1514) Albrechta Dürera oraz współczesnym wariantom melancholii zauważa, iż „Saturn uwolnił swoje dzieci od historii” (Grass 1991, 230). Melancholik krytycznie odnosi sie do heglowskiej i marksistowskiej koncepcji procesu historycznego. XIX-wieczna refleksja o Historii zakłada, iż toczy się ona ruchem prostolinijnym, istnieje w niej logiczny rozwój i postęp (Arendt 1991, 51-52, 54; Bieńczyk 2002, 22). Podmiot melancholijny jest przeciwny każdej holistycznej wizji Historii (Bieńczyk 2002). Dzieje jawią mu się nie jako harmonijna struktura, dążąca do wyznaczonego celu, ale jako zbiór fragmentów pozbawionych wspólnego sensu. Georg W.F. Hegel twierdząc, że elementy bytu są rozumne i dobre, nie wyraża zgody na moralną krytykę faktycznego stanu rzeczy, a zakorzeniony w przeszłości melancholik nie podchodzi entuzjastycznie do tego, co ma miejsce "teraz”. Według

\footnotetext{
1 Skorzystam z następujących wydań utworów: Brandys 1946; Kisielewski 1947; Hertz 1948. Zastosuje skróty: DK - K. Brandys, Drewniany koń; SP - S. Kisielewski, Sprzysiężenie; $S$ - P. Hertz, Sedan; UKL - P. Hertz, Ucieczka z Krainy Lambertów; PE - P. Hertz, Porwanie Europy.

2 Melancholię podporządkowano Saturnowi w czasach antycznych. W kanonicznej literaturze melancholijnej planeta ta stała się symbolicznym przedstawieniem egzystencji pogrążonej w smutku. Zob. Klibansky R., Panofsky E., Saxl F. 2009, 157-182.

${ }^{3}$ Stosunek bohaterów prozy rozrachunkowej do Historii jest jednym z wielu rodzajów postaw przyjmowanych przez inteligentów ukazanych w polskiej literaturze powojennej. Przykłady literackie, jak i te spoza literatury dowodzą, że reakcje na procesy historyczne mogą być różnorodne. Wyznawanie ideologii nazistowskiej, marksistowskiej czy też odnoszenie się do nich z dystansem to tylko niektóre z możliwych do przyjęcia stanowisk.
} 
niemieckiego filozofa koniec Historii to jednocześnie jej szczęśliwe spełnienie, melancholia natomiast wyklucza zamknięcie, wpisana jest w nią figura braku. Dzieciom Saturna obca jest również marksistowska fascynacja przyszłością, w której urzeczywistnia się idylla komunizmu - Historię postrzegają jako stopniowy upadek, bezcelowe odchodzenie od prawdy (Grass 1991, 216; Bałus 1996, 43; Cioran 2008).

Opisany sposób interpretowania Historii zajmuje szczególne miejsce w refleksji, obdarzonego melancholijnym temperamentem, Waltera Benjamina (Sontag 1994, 24-31). Twierdzi on, że ucieleśnieniem procesu dziejowego jest rumowisko, będące metaforą przemijania Historii i upadku natury (Frydryczak 2002, 138). Najważniejsze założenie reprezentowanej przez niego filozofii dziejów wyraża się w alegorii „anioła historii” (Benjamin 1996, 413-425; Najdek 2010, 134; Frydryczak 2002, 109-126; Dziamski 1993). Autor Pasaży odwołuje się do wizerunku istoty anielskiej przedstawionej przez Paula Klee na obrazie Angelus Novus (1920), będącej znakiem kresu ludzkości, przepełnionej cierpieniem i błądzeniem. Inną postacią odgrywającą ważną rolę w jego polemice z Karolem Marksem jest Mesjasz, który nie przychodzi na końcu historii ludzkości, ale w dowolnym jej momencie (Najdek 2010, 135; Sauerland 1986, 144; Bauman 1993, 22, 24). Apokaliptyczna katastrofa zostaje zastąpiona wyobrażeniem codziennej, zwyczajnej zagłady. Za pomocną figury Mesjasza filozof kwestionuje marksistowski komunizm, który - jako idealny etap procesu historycznego miałby być jego zamknięciem. Opowiada się za Historią rozumianą jako akt niczym nieograniczonej kreacji, w którym wszystkie chwile mają wartość.

Melancholijne postrzeganie dziejów odnajdujemy też w myśli Emila Ciorana, rozpoznającego ich dramatyczny wymiar związany $\mathrm{z}$ pełną sprzeczności naturą kształtujących je ludzi (Cioran 2008, 71, 128-129; Bieńczyk 2002, 326, 334). W stanowisku intelektualisty widzimy wpływy manichejskie - obecność jednostki w rzeczywistości historycznej definiuje jako „upadek w czas” i zaznacza, że pojawianie się Historii zniszczyło stan pierwotnej jedności oraz wpisało w istnienie zło. Proces dziejowy ogranicza człowieka, powoduje, że jest zdeterminowany przez reguły konkretnego życia. Należy podjąć próbę funkcjonowania poza granicami Historii, bowiem jest ona mniej ważna od prywatnych doświadczeń każdej jednostki.

\section{Nowy wymiar bierności}

Melancholijna postać na rycinie Dürera Melancholia I pogrążona jest w bezczynności. Trudno precyzyjnie stwierdzić, czy nie zaczęła jeszcze wykonywać swoich obowiązków, czy porzuciła je nagle w środku dnia, nie troszcząc się, ile zostało jeszcze do zrobienia. Fakt, że siedzi nieruchomo, z wpatrzonym w dal spojrzeniem, nie oznacza jednak, iż opanowała ją całkowita bierność. Stagnacja dzieci Saturna wiąże się bowiem z wewnętrzną aktywnością, niepotrafiącą się przejawiać (Vitale 1987, 57). Podmiot 
melancholijny, rozumiejąc, iż realność nie obejmuje samej rzeczywistości zewnętrznej, ale mieści się również w przestrzeni mentalnej, nie musi się poruszać, by pozostawać w stanie witalności. Wie dobrze, że „im bardziej bolesną jest utrata świata, tym intensywniejsze pogrążenie się w tym, co wewnętrzne" (Lepenies 1997, 151). Dürer w dziele Melancholia I połączył ars geometria z homo melancolicus, nadając marazmowi melancholika nowe sensy (Klibansky, Panofsky, Saxl 2009, 343-344). Ukazana postać tkwi w bezczynności, ponieważ pochłonęły ją problemy ważniejsze od praktycznego działania. Znakami jej ukrytego, bo intelektualnego, ruchu są zaciśnięta pięść podpierająca głowę i wpatrzone w dal spojrzenie, którego każda z osi biegnie w odmienny sposób, co jest charakterystyczne dla wysiłku umysłowego. Nieprzypadkowo też artysta zderzył zewnętrzne odrętwienie Melancholii z ruchliwością putta. Energicznie rysujące coś dziecko symbolizuje działanie połączone z brakiem myśli i świadomości - widzimy, że vita activa i vita contemplativa znoszą się wzajemnie (Panofsky 1971, 284). Brak zaangażowania w sprawy świata jest niezbędnym elementem melancholijnej kontemplacji rzeczywistości i postawy poznawczej dzieci Saturna (Hersant 1992, 282; Zaleski 1996, 25). Fizyczny marazm z jednej strony sprzyja procesowi introspekcji i wzrostowi samoświadomości (Klibansky, Panofsky, Saxl 2009, 261), z drugiej jest ich nieuchronną konsekwencją. Im lepiej melancholik rozumie siebie i otoczenie, tym uporczywiej trwa w zewnętrznej bezczynności, stając się - jak trafnie pisze Cioran - człowiekiem „straconym dla życia” (Cioran 1992, 77).

Typowego dla podmiotu melancholijnego wycofania z udziału w przestrzeni historycznej nie należy zatem uznawać za wyraz bierności, przeciwnie - trzeba traktować je jako szczególną formę działania. Przebywając na marginesie dziejów, znajduje się on w stanie psychicznego i intelektualnego ruchu, zajmuje się stawianiem diagnoz egzystencjalnych, społecznych czy politycznych. Pragnie zamanifestować własną niechęć do koncepcji procesu dziejowego i wpisanej w niego idealistycznej wizji przyszłości.

\section{Wpływ Saturna na wojenne losy bohaterów}

\section{Obojętność na Historię w kilku odsłonach}

Relacja między jednostką a Historią jest jednym z najważniejszych wątków prozy rozrachunków inteligenckich, a w szczególności pisarstwa Brandysa (Wysłouch 2011, 127-147). Mimo wykorzystywania różnorodnych form narracyjnych i gatunkowych twórca, jak sam wyznaje w Miesiącach, zawsze starał się znaleźć odpowiedź na pytanie: „Czy, albo do jakiego stopnia, można stworzyć własne przeznaczenie, niezawisłe od Opatrzności i Historii?" (Czyżak 1998, 7).

Inteligent sportretowany w Drewnianym koniu subiektywnie postrzega działania zbrojne mające miejsce w trakcie II wojny światowej i nadaje im własne, niezależne od uwarunkowań historycznych sensy. Już na 
pierwszych stronach dziennika narrator akcentuje swoją pełną wycofania postawę i to, że rzeczywistość wojenna nie wyznacza mu kierunku myśli i kolorytu uczuć. Zbliżająca się wojna wymaga pełnej mobilizacji, tymczasem introwersja i lenistwo melancholika rosną. Wypełniająca miejską przestrzeń atmosfera podekscytowania i napięcia nie ma na niego wpływu - tworzy jedynie drażniący „zgiełk”, o którym wspomina enigmatycznie. Okupacyjne dni upływają mu na czytaniu książek, grze w karty bądź szachy, pisaniu pamiętnika oraz analizowaniu zakamarków duszy. Najtrudniejszym momentem jest zmiana miejsca zamieszkania, drastycznie pogarszająca i tak już depresyjny nastrój inteligenta. Przywiązanie do mebli pochodzących z rodzinnego domu, których nie udało się uratować, staje się ważniejsze od udziału w walce.

Percepcja konfliktu zbrojnego bohatera zasadniczo różni się od tego, jak odbierają go inni ludzie. Huk ognia artyleryjskiego to dla niego głównie akustyczne tło twórczej pracy. Okupacja okazuje się przestrzenią, w jakiej dobrze funkcjonują pamięć i wyobraźnia. Przeszłość jest bardziej realna od działań wojennych, w których melodię wsłuchuje się, nie mogąc w nocy zasnąć. Oglądane przez okno rumowisko kamienicy nakłania go do medytacji nad kondycją bytu i pielęgnowania katastroficznych myśli. Wojna, zamiast wywoływać przerażenie i niepokój, pozwala osiągać stan jedności z rzeczywistością zewnętrzną. Nawet bierna obserwacja wydarzeń daje melancholikowi szansę zbudowania bliskiego kontaktu z otoczeniem, dzięki czemu jego egzystencjalna samotność zmniejsza się, a on zdobywa poczucie, że jest elementem niezbędnym, by istniała powszechna harmonia. Wierzy także, iż okupacja może być źródłem niebywałych i intensywnych emocji. Zamiast cieszyć się z uniknięcia niebezpieczeństwa, domaga się pojawienia się okoliczności, w które byłyby wpisane groza i niepewność. Kiedy wieczorem odwiedza go Gospodarz z psem, przeżywa rozczarowanie. Widząc w świetle lampy znajomą twarz, pyta rozżalony: „A więc tylko tyle? (...) Więc tylko to?" (DK, 74).

Melancholik manifestuje niezależność od Historii, usuwając ze swojego języka słowa wywołujące „wojenne” konotacje. Nigdy nie wskazuje na narodowość okupanta - Niemcy to jedynie „żołnierze”, krzyczący w „rozzłoszczonym dialekcie” $(D K, 14)$. Wojska wroga są anonimowymi „najeźdźcami”, którzy „objęli władzę” ( $D K, 111)$. Gestapowcy nie kojarzą się z oprawcami, ale z dobrze wyposażoną ekspedycją badawczą - wyglądają raczej jak „wyprawa naukowa niż coś złego” (DK, 113), a w rękach trzymają „dziwaczne przedmioty ze stali, podobne na pierwszy rzut oka do przyrządów naukowych używanych przez badaczy ziemi" $(D K, 113)$. Tak ogólne określenia bohater stosuje nie tylko wobec Niemców, obejmuje nimi też walczących Polaków - uważa, że „żołnierze obydwóch wojsk” zginęli $\mathrm{w}$ „niedawnej bitwie” (DK, 14).

Obecność inteligenta $\mathrm{w}$ rzeczywistości polityki przypomina udział w spektaklu teatralnym bądź dziecięcą zabawę w wojnę. Pokazuje 
to przebieg zebrania tajnej organizacji OKO, w czasie którego melancholik wciela się w rolę delegata Najwyższej Komendy Czynu i bezkrytycznie wypełnia wszystkie dyrektywy Doktora. Precyzyjnie wyreżyserowane przedstawianie jest dla niego, paradoksalnie, obszarem wolności, którego granice wyznacza twórcza kreacja, oraz momentem, w jakim obserwując własną grę z boku, może być dla siebie przedmiotem ciekawości. Choć jest na spotkaniu spiskowców osobą najważniejszą, to od dziejącej się Historii zdaje się być oddzielony grubą szybą. Jego izolację potęguje nastawienie na wychwytywanie sygnałów płynących z przestrzeni znajdującej się poza pomieszczeniem gromadzącym spiskowców - słyszy wiatr, wiejący za oknem, i padający deszcz. Chciałby również jak najszybciej znaleźć się w swoim mieszkaniu, którego znakiem staje się bijący za ścianą zegar. To jego dźwięk rodzi w nim świadomość przynależności do miejsca innego niż to, w jakim aktualnie przebywa.

Niechęć bohatera wobec Historii jest tak silna, że nawet ciało angażuje się w umacnianie dystansu do faktów politycznych. Kondycja fizyczna melancholika odgrywa ważną rolę w tworzeniu relacji między nim a porządkiem dziejów i łatwo rozpoznać w niej treści symboliczne. Na początku wojny przebywa w szpitalu, w którym spędza „trzy miesiące z naruszonym kręgosłupem, wstrząśniętym mózgiem i sercem zobojętniałym na historię" (DK, 186). Wymienione obrażenia nabył wskutek wypadnięcia przez okno podczas zapuszczania rolet. Przygotowując mieszkanie na ewentualny atak nieprzyjaciela, rozmyślał nad naturą procesu historycznego. Żałował, że musi robić to, co dyktuje Historia, zamiast korzystać z uroku ciepłego, wrześniowego wieczoru. Zdarzenia najbanalniejsze, ale samodzielnie wybrane i wykreowane, są dla niego istotniejsze od szlachetnych działań służących dobru ojczyzny. Wojnę postrzega jako okoliczność zabierającą czas, swobodę oraz możliwość racjonalnego myślenia. Obowiązek zasłaniania rolet nie pozwala przecież spokojnie zanurzyć się w rzeczywistość myśli - moment nieuwagi kończy się poważnym wypadkiem. Historia wymusza na jednostce konieczność czynu, każda próba zatrzymania się i analizowania dziejących się wydarzeń obraca się przeciwko kontemplującemu świat podmiotowi. Melancholik wie, że po wyjściu ze szpitala znów będzie musiał reagować na jej istnienie, zabiegać, by w dyktowanych przez nią warunkach stworzyć niewielką, własną przestrzeń. Podejrzenie to sprawia, że żałuje, iż ocalał i dostrzega absurdalność wyroków przeznaczenia. Skutki przeżytego wstrząsu mózgu i uszkodzenia kręgosłupa odczuwa przez całą okupację - w trakcie bezpośredniego kontaktu z realiami wojny ma wysoką gorączkę, dreszcze, zawroty głowy, cierpi na bezsenność i omdlenia. Wypadek i jego konsekwencje należy uznać za reakcję inteligenta na prawidłowości rządzące Historią. Są symbolicznym gestem protestu przeciw bezwzględności dziejów, wyrazem opowiedzenia się po stronie indywidualnych potrzeb jednostki, której suwerenność i umiejętność krytycznego oglądu świata nie powinny być kwestionowane. Fizyczne choroby podmiotu melancholijnego 
Bieńczyk interpretuje jako przykład walki ciała z duchem epoki i podkreśla, że z łatwością reaguje ono na Historię, bowiem reprezentuje ten sam co ona porządek (Bieńczyk 2002, 24, 166-167). Sportretowany melancholik czuje się przez dzieje osaczony i chorując, szuka dróg ucieczki. Mdleje, by przejść w upragniony stan historycznego nieistnienia.

Sensy metaforyczne, związane z polityczną awersją inteligenta, dostrzegamy także w tytułowym drewnianym koniu - innym symbolu melancholijnej bierności. Gdy bohater spędzał na nim długie godziny w dzieciństwie, nie ujawniał swoich potrzeb i nie egzystował autonomicznie. Imię drewnianego konia - Hektor - posiada wydźwięk ironiczny. Znaczenia zawarte w zabawce na kółkach są zaprzeczeniem zarówno cech kulturowo przypisywanych najdzielniejszemu rycerzowi trojańskiemu, jak i wpisanych w symbolikę prawdziwego konia - znaku bohaterstwa, władzy, odwagi czy wojny (Kopaliński 1990, 158-159). Obraz chłopca trwającego nieruchomo na drewnianej zabawce kojarzy się z pomnikami wybitnych dowódców, upamiętnianych często na rumakach, towarzyszących im na polach bitewnych. Podobieństwo między nim a zwycięskimi wodzami jest oczywiście pozorne - przypomina on raczej „pomnik własnego dramatu” (DK, 24), wspólnie z koniem stanowią karykaturę konnej rzeźby. W powieści występuje przekształcenie symboliki mitologicznego Hektora, który staje się metaforą bierności, lęku przed światem i niechęci do podejmowania jakiejkolwiek aktywności. Konika na kółkach można uznać za miniaturę konia trojańskiego postawionego przez Greków pod murami Troi - symbolu podarunku przynoszącego nieszczęście (Kopaliński 1985, 515). Koń, którego otrzymał bohater utworu Brandysa, również sprowadza na niego katastrofę - zaszczepiona $\mathrm{w}$ dzieciństwie postawa bierności jest jego jedyną formą kontaktu z rzeczywistością w dorosłym już życiu. Mały chłopiec siedzący na drewnianym kucyku to alter ego melancholika, jego „wierny bliźniak”, który jest „nieodłączny jak cien”” ( $D K, 24)$.

Podobnie Zygmunt, bohater Sprzysiężenia Kisielewskiego, wielokrotnie rozmyśla o kwestiach politycznych oraz dyskutuje na ich temat w redakcji „Polityki i Sztuki”, ale - jako typowy melancholik - tak naprawdę nie jest nimi zainteresowany. Przedmiotem jego prawdziwej pasji jest działalność artystyczna. Sceptycznie odnosi się do Historii, której kierunek i rytm wyznaczają zwykle ruchy masowe, wykorzystujące emocje tłumu, a lekceważące jednostkową umiejętność krytycznego myślenia. Wie, że jego "ja” „w pierwszym rzędzie jest dlań realne i godne ocalenia - bardziej niż jakakolwiek masa" $(S P, 344)$. Indywidualizm traktuje jako tarczę izolującą przed naporem procesu historycznego. Ułatwia on realizację tak podstawowej wartości jak godność, a w warunkach wojennych przyjmuje postać egoizmu, potęgującego wolę przetrwania. Wiara bohatera w niezwykłość każdej jednostki, którą należy chronić przed bezwzględnością dziejów, stanowi konsekwencję wnikliwej obserwacji własnego świata duchowego i przekonania o jego suwerenności. Jako zwolennik indywidualizmu Zygmunt nie godzi 
się na wpisaną w nazizm nienawiść wobec tego, co jest niezgodne z naszym światopoglądem. Negatywnie odnosi się również do marksizmu, któremu zarzuca naiwne sprowadzanie złożonych mechanizmów funkcjonowania rzeczywistości do jednej zasady materializmu dziejowego. Potępiając nazizm i marksizm, odcina się od myślenia utopijnego.

Własne występowanie na scenie Historii bohater bierze pod uwagę tylko wówczas, gdy może swoją rolę podporządkować osobistym potrzebom i sposobowi widzenia rzeczywistości. Kiedy postanawia wziąć udział w działaniach zbrojnych, nie potrafi po prostu założyć munduru i stać się walczącym o niepodległość żołnierzem. Od poświęcenia dla Polski istotniejsze okazują się powody całkowicie prywatne, o naturze psychologicznej, społecznej, egzystencjalnej i seksualnej. Z wojny uczynił przestrzeń, w której spełniają się marzenia, rodzi się nadzieja na radykalną przemianę, zapewnia mu ona „ratunek przed sobą samym” $(S P, 258)$. We wrześniu 1939 roku samopoczucie melancholika polepsza się, nie ma już czasu zamartwiać się sprawami dotąd wypełniającymi jego codzienność. Stan izolacji znika, gdy widzi, że wszyscy doznają tak dobrze znanych mu uczuć: zagubienia i niepewności. Okupacja stwarza także warunki do zaangażowania się w działanie, pozwala poruszać się w sferze realnej, z którą obcowanie jest mniej bolesne od konfrontacji z myślami i wyobrażeniami. Zygmunt wierzy, iż starcia zbrojne nadadzą wartość jego życiu, jako żołnierz nie będzie miał egzystencjalnych wątpliwości i skończy się nieustanna próba ustalania w świecie punktów orientacyjnych. Na froncie szybko określi własną tożsamość - jego egzystencja zamknie się w dwóch prostych słowach: „jestem żołnierzem” (SP, 274). Takie funkcjonowanie jawi się bohaterowi jako rodzaj sportu, którego uprawianie gwarantuje zdrowie i szczęście. Ważny sens działań zbrojnych rozpoznaje też w akcie seksualnym, do którego właśnie w czasie okupacji okazuje się zdolny. II wojna światowa wyznacza granicę młodości inteligenta i wprowadza go w dojrzałość. Udział w niej wyzwala Zygmunta od stanów melancholijnych. Po jej ustaniu jest przekonany, że „wyprostowała wszystko i oczyściła wszystko” (SP, 353).

Adam Lambert, bohater Sedanu Hertza, w trakcie licznych podróży po Europie ma szereg możliwości zapoznania się z aktualnymi wydarzeniami politycznymi. Nie zajmuje się nimi jednak, ponieważ jest zdania, że nie mają wpływu na jego prywatne - a więc właściwe - życie. Dziękuje losowi, że zawsze znajdzie miejsce, do którego łatwo uciec „przed ogromnym czołgiem ze swastyką" $(S, 64)$. Mapa Europy jest dla niego jedynie terenem turystycznej eksploracji i przedmiotem estetycznej kontemplacji. Patrzy na nią wówczas, gdy planuje trasę kolejnej wyprawy. Podróżuje po europejskich miastach szczelnie odizolowany od życia toczącego się w kawiarniach i na bulwarach - zatrzymuje się tylko w luksusowych hotelach i sanatoriach. Mimo że wszędzie pachnie już „prochem i krwią”, on czuje wciąż „wonne zapachy wody kolońskiej, czystej bielizny i dobrego tytoniu" $(S, 18)$. 
Odmowa uczestnictwa w Historii oznacza w jego przypadku naiwną interpretację zjawisk i brak elementarnej wiedzy o tym, co dzieje się w Europie. Małe chorągiewki ze swastyką, które w przededniu wojny zauważa na mapie Niemiec, wiszącej w witrynie Niemieckiego Biura Podróży, nie prowokują go do namysłu nad przyczyną swojego pojawienia się. Żałuje, że zbyt gwałtownie spojrzał w lewą stronę - gdyby tego nie uczynił, jego wzrok w ogóle nie natknąłby się na nie. Decyduje się wyruszyć w planowaną podróż. Gdy po pewnym czasie zauważa brak chorągiewek, dochodzi do wniosku, że zostały usunięte, ponieważ wyblakły. Nieistnienie linii granicznej między Bawarią i Austrią wywołuje w nim z kolei podejrzenie, że twórcy nowej mapy zapomnieli ją zaznaczyć. Informacja o wcieleniu Austrii do Trzeciej Rzeszy w pamiętniku nie pada. O całkowitym braku orientacji melancholika w kwestiach politycznych świadczy także to, że nie jest w stanie określić, dlaczego nie darzy sympatią Niemców - na jego stosunek do nich nie wpływa bowiem - jak wyznaje - publiczne palenie książek ani zakładanie obozów koncentracyjnych. Dystans bohatera do Historii został utrwalony na fotografii wykonanej przez jednego z Niemców, gdy nastąpił anschluss Austrii. Inteligent jest na niej „zastygły, nieruchomy, wsparty o latarnię gazową, trzymając u czoła fularową chusteczkę" $(S, 63)$.

\section{Rumowiska melancholii}

Ruiny są istotnym elementem melancholijnego nastroju, ponieważ stanowią „świadectwo kruchości dzieł ludzkich i bezskuteczności ich naprawiania" (Jadacki 2005, 47). Ich związek z melancholią tkwi w tym, że - podobnie jak ona - ewokują zagadnienie nieobecności. Przypominają, że czas miniony został utracony, a jego znaczenie bezpowrotnie zatarte (Starobinski 1996, 150-151).

W prozie rozrachunkowej rumowisko stanowi metafore Historii i następujących w niej przemian oraz odnosi się do miejsca, jakie zajmuje w społecznej strukturze reprezentowane przez bohaterów środowisko. Postać ruin przyjmuje także przestrzeń miast w wyniku kontaktu z procesem dziejowym i wpisanym w nie przemijaniem.

W Sedanie Hertza motyw ruin odgrywa kluczową rolę. Trzy utwory (z czterech umieszczonych w omawianym tomie opowiadań) dotyczą problematyki upadku, którą wskazują już same tytuły: Sedan, Ucieczka $z$ Krainy Lambertów oraz Porwanie Europy. Dla Lamberta historia to nie ciąg sukcesów i zwycięstw, lecz pasmo porażek. Głównym faktem politycznym, który zapamiętał ze szkolnych lekcji historii, było starcie prusko-francuskie pod Sedanem. Słowo „Sedan” w jego pamięci zapisało się nie tylko jako synonim klęski Francji, ale także jako symbol wszystkich upadków państw i systemów politycznych. Uczynił z niego również metaforę każdej klęski jednostki pokonanej przez Historię. Katastrofy towarzyszące procesowi dziejowemu postrzega jako osobistą apokalipsę pojedynczego człowieka, 
jest przekonany, że to, co kształtuje rzeczywistość społeczno-polityczną, oddziałuje też na przestrzeń prywatną zwyczajnych ludzi. Bieg dziejów oznacza nieustanne cierpienie - inteligent porównuje go do drogi krzyżowej Chrystusa. Wpisane w Historię przemijanie nakłada się na kruchość ludzkiego życia, a jedynymi trwałymi wartościami okazują się ukryte w pamięci wspomnienia. Melodię zagłady melancholijne ucho bohatera wychwytuje już w brzmieniu słowa „Sedan”, które przypomina dźwięk wydawany przez spróchniałe drzewo staczające się ze zbocza wzgórza. Ruch w dół wzmacnia wanitatywną i katastroficzną wymowę myśli melancholika. To w czasie pobytu w Paryżu Adam uświadamia sobie, że przeczuwana od dawna klęska wkrótce po raz pierwszy nabierze rysów realnych - przyjmie postać kolejnej wojny. Wykonując poranną toaletę, nie może oprzeć się wrażeniu, iż te rutynowe, codzienne czynności wykonuje ostatni raz. O katastrofie myśli także wtedy, gdy dokonuje się anschluss Austrii w marcu 1938 roku. Kiedy widzi na ulicach Wiednia czerwoną chorągiew ze swastyką, wyglądającą „jak sieć, którą za chwilę zarzuci pilny $\operatorname{rybak}^{\prime}(S, 62)$, wie, że jest świadkiem zagłady. Nieprzypadkowo również pociąg, którym wraca przed wybuchem wojny ze stryjem do Polski, zatrzymuje się właśnie na stacji Sedan. W czasie podróży stale towarzyszy mu poczucie nieuchronności wojennej apokalipsy. Podejrzewa, że sam będzie musiał w niej uczestniczyć - pociąg jedzie „w stronę klęski”, a on, siedząc w nim, zmierza „w stronę własnego przeznaczenia" $(S, 77-78)$. Uważa, że zagłady wpisanej w Historię nie sposób ominąć. Prawidłowości rządzące procesem dziejowym są absolutne, a bezsilna wobec nich jednostka może tylko „patrzeć, jak toczą się dzieje” (UKL, 128). Człowiek protestujący przeciw nieuchronności historycznego porządku zostanie przez niego bezlitośnie zniszczony. Świadomość nadchodzącej klęski, mającej wymiar totalny, bo obejmujący całość dotychczasowego świata, wprawia Adama - jak sam wspomina - w stan melancholii. Odczuwa go nie tylko dlatego, że widzi, iż katastrofa jest nieunikniona, ale ponieważ nie potrafi określić momentu jej nadejścia i podać kierunku, z którego przybędzie. Niepewność nie pozwala w pełni angażować się $\mathrm{w}$ tworzenie życia ani nie daje prawa do całkowitego się $\mathrm{z}$ niego wycofania - skazuje na trwanie w zawieszeniu.

Prześladujący Lamberta obraz upadku bezpośrednio wiąże się z jego własnym losem, ponieważ jest przekonany o rychłej klęsce mieszczaństwa. W pamiętniku chce ukazać rzeczywistość, w której żyli przedstawiciele warstwy społecznej, jaką reprezentuje - charakterystyczną „dla niedawno umarłego czasu" $(S, 15)$. Przyczyn zbliżającego się kresu zamożnego mieszczaństwa upatruje w zasadach, jakimi kieruje się Historia, ale także w trybie życia jego przedstawicieli. W nich samych dojrzewa każdego dnia ich własny Sedan. Majątki, za pomocą których definiują siebie i rzeczywistość, widząc w niej tylko dwa przeciwstawne bieguny: „mieć” i „nie mieć", wkrótce zamienią się w pokrywające całą Europę rumowisko. Adama też nie ominie zagłada, będąca karą za to, że nie próbował być przydatny 
innym ludziom i społeczeństwu w ogóle. Historia wystąpi w roli sędziego i wymierzy sprawiedliwe wyroki.

Liczne fragmenty pamiętnika bohatera Drewnianego konia Brandysa również sprawiają wrażenie, jakby ich autor, myśląc o dziejach, miał przed oczami Benjaminowskiego „anioła historii”. Jako melancholik nie wyobraża sobie przyszłości i jest zdania, że Historia dąży ku upadkowi. Ruiny, znajdujące się w pobliżu zaułka, w którym mieszka, umacniają go w przekonaniu, że ślady apokalipsy są rozpoznawalne w teraźniejszości. Co ważne, to nie wojna przyniesie ostateczny kres, jest ona jedynie preludium właściwej zagłady. Po zakończeniu walk od strony Wschodu nadciągnie klęska, której nie da się uniknąć. Dostrzegamy obawy inteligenta przed zmianami ustrojowymi w powojennej Polsce. Realizacja marksistowskiej ideologii to mający się urzeczywistnić kataklizm.

Nadchodzący koniec bohater Drewnianego konia odczytuje w dwóch aspektach: zbiorowym i indywidualnym. Wierzy, że w najbliższym czasie nastąpi upadek jego własny i grupy społecznej, którą reprezentuje. Gdy zastanawia się, dlaczego zawsze funkcjonował w oderwaniu „od wszelkich wstrząsów dziejowych" ( $D K, 9)$, wyznaje, iż częściowo za jego bierność odpowiada środowisko zamożnego mieszczaństwa. Koniec idei i wartości, z którymi się identyfikuje, wydarzy się tak samo szybko jak katastrofa całej ludzkości. Porównuje się do władcy pozbawionego tronu przez Historię obierającą niewłaściwy kurs.

Rumowisko może być także formą, jaką przyjmuje zniszczone w trakcie II wojny światowej miasto. Zagłada Warszawy ukazana w Sedanie jest tak wielka i nieprawdopodobna, że Adam Lambert z żadnym innym zniszczeniem nie może jej porównać. Gruzy stolicy wstrząsają nim bardziej niż zgliszcza antycznego Rzymu czy Grecji. Szczególnie uderza go szybkość, z jaką została zrównana z ziemią - Kapitol i Akropol potrzebowały setek lat, by osiągnąć obecną postać, ona zamieniła się w ruiny w ciągu kilkunastu miesięcy. Mimo że spacer po zbombardowanej Warszawie jest dla inteligenta doświadczeniem traumatycznym, to jednak decyduje się na uważną i długą kontemplację zgliszczy. Dąży do pozostawania z nimi w bezpośredniej, osobistej relacji. Lornetka ma przybliżać mu obserwowane obiekty. Bolesne jest odnajdywanie wśród ruin śladów ludzkiej codzienności - zwyczajnych sprzętów, które wypełniały dom rodzinny bohatera, sprawiając, że rzeczywistość stawała się oswojona i przyjazna. Obecne istnienie przedmiotów wśród gruzów uświadamia melancholikowi upływ czasu, fakt, że jego młodość odeszła dawno w przeszłość.

Inteligent zdaje sobie sprawę, iż o zniszczeniu Warszawy nie zdecydowały tylko działania zbrojne. Gdy spaceruje po rumowisku miasta, dostrzega, że zaczęła je porastać wiosenna trawa i uzyskało ono „nieludzkie” oblicze. Podobne refleksje rodzi w nim wygląd posiadłości Lambertów, przemienionej w dom roślin i zwierząt. Do ostatecznego upadku stolicy przyczyniły się również siły natury, które stopniowo przejęły stworzone przez Historię 
gruzy w swe posiadanie. Za całkowity rozpad form architektonicznych odpowiedzialne są zawsze przeciwstawne porządki: kreowany przez człowieka bieg dziejów oraz niezależna od niego przyroda. Rumowisko znajdując się na pograniczu tych dwóch światów, tworzy zupełnie nową jakość (Simmel 2006, 171).

Paradoksalnie, bohater dostrzega zgliszcza w przestrzeni Warszawy na długo przed tym, zanim jej elementy zostały zburzone. Tak doświadczane miasto staje się rzeczywistością fantasmagoryczną, o trudnym do zdefiniowania statusie. Patrząc na stolicę, nie widzi jej kształtów i barw, lecz „zalążek ruin" $(S, 8)$. Zawsze miał pewność, że Warszawa została zbudowana na braku: w takim samym stopniu istniała, jak była nieobecna. Obraz zniszczonego miasta inteligent rozpoznaje we wszystkich stolicach europejskich, do których dociera w trakcie swych podróży. Co ciekawe, gdy ogląda starożytne rumowiska na południu starego kontynentu, nie dostrzega zapamiętanego z lekcji historii Sedanu. Zagładę ewokują natomiast tętniące życiem metropolie u szczytu cywilizacyjnego rozwoju. Adam wyznaje, że klęskę, która „wisiała nad Paryżem”, najlepiej było widać „o świcie z wysokiego wzgórza Sacre-Coeur" $(S, 72)$. W opisie początku dnia występuje przekształcenie symboliki tradycyjnie w niego wpisanej - wschód słońca nie jest zwiastunem narodzin, ale zapowiedzią śmierci.

\section{W obronie inteligenta}

W pierwszym powojennym dziesięcioleciu powróciła dyskusja na temat roli i genealogii polskiej inteligencji (Palska 2008, 168-175; Habielski 2008, 227-231). Spór wiązał się z trudnym położeniem, w jakim znalazła się ta warstwa społeczna w wyniku II wojny światowej, a także z podporządkowaniem Polski w 1945 roku władzom komunistycznym. Pretensje kierowane przez marksistów pod adresem inteligencji były próbą zdegradowania jej społecznego i politycznego prestiżu oraz dążeniem do zdeprecjonowania wyznawanego przez nią etosu. Wielokrotnie wyrażano je na łamach „Kuźnicy”, pisma stanowiącego instrument partyjnej propagandy. Tu także ukazało się najwięcej negatywnych recenzji utworów zaliczonych przez Wykę do nurtu rozrachunków inteligenckich. Studium, w którym badacz wyróżnił ten prąd, żałując, iż dawna, aktywna postawa inteligencji stała się obecnie jedynie konwencją literacką, można uznać za podsumowanie zarówno opublikowanych w „Kuźnicy” odczytań powieści, jak i toczącej się w piśmie dyskusji.

Bierność bohaterów prozy rozrachunkowej jednak tylko pozornie wpisuje się $\mathrm{w}$ propagowaną przez władzę komunistyczną krytykę inteligencji. W istocie broni ona przedstawicieli tej grupy, którzy nie chcąc zaakceptować heglowsko-marksistowskiej wizji procesu historycznego, świadomie się z niego wycofują. Kategoria melancholii pozwala pokazać, że negowana w latach 40 . „inteligenckość” to tak naprawdę zaleta 
bohaterów, składające się na nią cechy świadczą nie tyle o społecznym pochodzeniu, co o podmiotowym przeżyciu egzystencjalnym. Typowa dla dzieci Saturna wizja dziejów każe im poszukiwać w przestrzeni Historii śladów ruin i zaszywać się w zamkniętych pokojach (Drewniany koń), luksusowych hotelach (Sedan) lub, paradoksalnie, w żołnierskich oddziałach (Sprzysiężenie). Okazuje się, że zewnętrzna nieruchomość jest niezbędna, by nastąpiła aktywność psychiczna i umysłowa, przejawiająca się w proteście przeciw machinie Historii. Niechęć inteligenta do bycia homo politicus wynika z tego, że zdaje sobie sprawę z ograniczeń nakładanych na jednostkę przez totalitarne ustroje i nie wierzy w możliwość urzeczywistnienia się faszystowskiej i komunistycznej utopii. Jego opór przeciw porządkowi dziejów zawiera się w próbie wyeksponowania ich wartości egzystencjalnej i prawie do indywidualnej oceny wydarzeń. Sytuację Polski po 1939 roku traktuje jako okazję do przeżycia ekscytującej przygody i zbudowania historii prywatnej, odmiennej od funkcjonowania zbiorowości.

\section{Inspiracje dydaktyczne}

Konieczność kształtowania postaw patriotycznych dzieci i młodzieży akcentuje podstawa programowa na każdym etapie edukacyjnym, jednak na lekcjach języka polskiego mówi się zwykle o sprawach ojczyzny patetycznie, za pomocą gotowych klisz językowych i tekstów o jednoznacznej wymowie. Taka edukacja patriotyczna nie jest skuteczna (Bortnowski 2012, 10-16; Kania 2015, 43). Współczesna szkoła funkcjonuje w świecie wieloznacznym i skomplikowanym, a klasa stanowi często środowisko wielokulturowe, w którym spotykają się osoby o odmiennym pochodzeniu, narodowości i wyznawanym systemie wartości. Przed nauczycielami stoi zatem zadanie wypracowania nowego sposobu rozmawiania o polskiej historii i propagowania zachowań obywatelskich. Należy uczyć postawy otwartości wobec ludzi reprezentujących inny światopogląd i pokazywać, że rzeczywistość nie jest czarno-biała. Specyfika lekcji języka polskiego sprawia, iż mogą one być obszarem, na którym doskonali się sztukę negocjacji i dyskusji, uczy empatii i tolerancji, czyli przygotowuje młodych ludzi na spotkanie z Innym w świecie zewnętrznym oraz w nich samych ${ }^{4}$. Trzeba pamiętać, że dla dzisiejszej młodzieży postęp technologiczny to zjawisko naturalne, dlatego edukacja polonistyczna, w tym kształcenie postaw patriotycznych, nie może odbywać się bez wykorzystywania elementów TIK, rozwijających kompetencje medialne i informacyjne uczniów (Strawa-Kęsek 2015, 102-118).

Wszystkie wymienione cele poloniści zrealizują, gdy przywołają na zajęciach prozę rozrachunkową z lat 40. Problematyka w niej obecna to dobry punkt wyjścia do rozważań o różnorodności stanowisk bohaterów literackich wobec Historii. Gdy porównamy podejście inteligentów z reakcją

${ }^{4}$ Kategoria inności jest popularna we współczesnej humanistyce i postuluje się jej obecność także na lekcjach języka polskiego. Zob. Edukacja polonistyczna wobec innego, 2014, Janus-Sitarz A. (red.), Kraków. 
większości postaci obecnych w szkolnych lekturach, oczywiste będzie, że o ojczyźnie można myśleć wielorako, nie zawsze zgodnie z romantycznym paradygmatem. Zaproponowane wskazówki metodyczne warto wykorzystać na pojedynczej lekcji lub w trakcie cyklu zajęć w ostatniej klasie szkoły średniej w ramach powtarzania materiału przed maturą. Można zastosować różnorodne metody dydaktyczne: problemową, projektu, pracy w grupach, pracy z tekstem literackim, drzewka decyzyjnego, mapę mentalną czy strategię przeżywania.

Zaczynamy od poproszenia uczniów o zapisanie skojarzeń ze słowem „ojczyzna”. W stworzonej mapie mentalnej mogą znaleźć się także związki frazeologiczne. Pytamy, czy wyraz jest neutralny uczuciowo, czy wywołuje jakieś emocje - jeśli tak, to jakie? Przywołujemy teksty literackie z epoki romantyzmu, pozytywizmu i II wojny światowej, których bohaterowie podejmują walkę za ojczyznę. Rysujemy oś życia wybranych patriotów, na której młodzież zaznacza najważniejsze momenty ich życia. Przypominamy, odwołując się do konkretnych przykładów, zjawisko języka ezopowego oraz różnicę między romantycznym i pozytywistycznym rozumieniem patriotyzmu.

Następnie podkreślamy, że istnieją również bohaterowie, którzy świadomie nie angażują się w sprawy politycznie. Dzielimy klase na cztery grupy. Każda ma przeczytać fragment jednego utworu rozrachunkowego: grupa I - Drewnianego konia Brandysa, grupa II - Sprzysiężenia Kisielewskiego, grupa III - Sedanu Hertza, grupa IV - Porwania Europy tego samego autora, a następnie odpowiedzieć na pytania znajdujące się na kartach pracy: 1) Jaką warstwę społeczną reprezentuje bohater i co o tym świadczy? 2) Jakie emocje przeżywa i o czym myśli? 3) Które zdania odnoszą się do kwestii politycznych i jak należy je odczytywać? 4) Na czym polega bierność bohatera? 5) Jaka forma narracji i jakie zabiegi językowe występują we fragmencie? Jaką pełnią funkcję? Po wykonaniu zadań liderzy zespołów prezentują wyniki pracy.

Nauczyciel zachęca, by młodzież „wczuła się” w sytuację inteligentów. Aby lepiej zrozumieć motywację bohaterów, przedstawiciele grup wcielają się $\mathrm{w}$ ich rolę, a pozostali uczniowie zadają im pytania dotyczące systemu wartości i dokonywanych wyborów. Portret psychologiczny melancholików będzie jeszcze pełniejszy, a zajmowane przez nich stanowiska bardziej zrozumiałe i bliższe młodym ludziom, gdy zaproponujemy przygotowanie drzewka decyzyjnego. Pomoże ono uczniom nie tylko „wejść” w położenie bohaterów, ale ułatwi namysł nad tym, jaki jest ich własny światopogląd i czy na miejscu inteligentów zachowaliby się podobnie. Problem, nad którym się zastanawiamy, brzmi: Jak reagować na Historię - aktywnie angażować się w walkę/protest czy przyjmować postawę bierną? Młodzież wypisuje wady i zalety wymienionych opcji, następnie każdy indywidualnie 
kończy w zeszycie zdanie: Oba stanowiska mają plusy i minusy, bliższa jest mi jednak postawa ..., gdyż ...

Zajęcia kończymy wysłuchaniem piosenki Kocham wolność zespołu

Chłopcy z Placu Broni. Pytamy o jej aktualność i inicjujemy dyskusję na temat współczesnej formuły patriotyzmu. Przypominamy, że utwór śpiewali Polacy, którzy w lipcu 2017 roku manifestowali w Warszawie przed Pałacem Prezydenckim, Sejmem i Senatem oraz w innych miastach Polski.

W domu uczniowie, pracując w zespołach, realizują jeden z projektów:

1. Zakładają blog wybranego bohatera prezentowanego na lekcji. Internetowy pamiętnik prowadzą przez tydzień, codziennie umieszczając krótki wpis. Punktem wyjścia powinno być wydarzenie opisane w lekturze lub wymyślone, ale zgodne z wymową utworu i charakterem epoki. Pod wpisami muszą się znaleźć komentarze innych przywołanych na zajęciach postaci literackich.

2. Przeprowadzają wywiady na temat: Na czym polega patriotyzm dzisiaj? Mogą poprosić swoich rozmówców (rodzinę, znajomych) o odniesienie się do ostatnich wydarzeń politycznych w Polsce oraz postarać się dotrzeć do zwolenników i przeciwników postulowanych przez rząd reform. Trzeba znaleźć w Internecie odpowiednie zdjęcia i filmiki, a całość złożyć w film za pomocą programu Windows Movie Maker lub przygotować prezentację multimedialną.

\section{Bibliografia}

Arendt Hannah, 1991, O rewolucji, Godyń M. (przeł.), Kraków.

Bałus Wojciech, 1996, Mundus melancholicus. Melancholiczny świat $w$ zwierciadle sztuki, Kraków.

Bauman Zygmunt, 1993, Walter Benjamin - intelektualista, w: „Drobne rysy w ciagłej katastrofie...". Obecność Waltera Benjamina w kulturze współczesnej, Zeidler-Janiszewska A. (red.), Warszawa.

Benjamin Walter, 1996, O pojęciu historii, w: Anioł historii. Eseje, szkice, fragmenty, Krzemieniowa K. (przeł.), Orłowski H. (wybór i oprac.), Poznań.

Bieńczyk Marek, 2002, „Dzień po” (Zakończenie), w: Oczy Dürera. O melancholii romantycznej, Warszawa.

Bieńczyk Marek, 2002, „Dzień przed” (Uwagi wstępne), w: Oczy Dürera. O melancholii romantycznej, Warszawa.

Bieńczyk Marek, 2002, Herezja i melancholia (O Emilu Cioranie), w: Oczy Dürera. O melancholii romantycznej, Warszawa.

Bieńczyk Marek, 2002, Oczy Dürera (O Zygmuncie Krasińskim i jego listach), w: Oczy Dürera. O melancholii romantycznej, Warszawa.

Bortnowski Stanisław, 2012, Jak uczyć patriotyzmu w XXI wieku, 70 lat po II wojnie światowej?, „Polski w Praktyce”, maj-czerwiec.

Brandys Kazimierz, 1946, Drewniany koń, Warszawa. 
Cioran Emil, 2008, Historia i utopia, Bieńczyk M. (przeł.), Warszawa.

Cioran Emil, 1992, Na szczytach rozpaczy, Kania I. (przeł.), Kraków.

Cioran Emil, 2008, Samotność i przeznaczenie, Dwulit A. (przeł.), Warszawa.

Czyżak Agnieszka, 1998, Kazimierz Brandys, Poznań.

Dziamski Grzegorz, 1993, Rehabilitacja alegorii. Baudelairowski motyw w refleksji nad sztuka współczesna, w: „Drobne rysy w ciagłej katastrofie...”. Obecność Waltera Benjamina w kulturze współczesnej, Zeidler-Janiszewska A. (red.), Warszawa.

Edukacja polonistyczna wobec innego, 2014, Janus-Sitarz A. (red.), Kraków.

Frydryczak Beata, 2002, Świat jako kolekcja. Próba analizy estetycznej natury nowoczesności, Poznań.

Grass Günter, 1991, O bezruchu w postępie. Wariacje na temat miedziorytu Albrechta Dürera „Melancholia I”, w: Z dziennika ślimaka, Błaut S. (przeł.), Gdańsk.

Habielski Rafał, 2008, Służba i wartości. Debaty o inteligencji polskiej (XIX-XXI wiek), w: Domański H. (red.), Inteligencja w Polsce. Specjaliści, twórcy, klerkowie, klasa średnia?, Warszawa.

Hersant Yves, 1992, Czerwona melancholia, Bieńczyk M. (przeł.), „Ogród. Kwartalnik", nr 2.

Hertz Paweł, 1948, Porwanie Europy, w: Sedan, Warszawa.

Hertz Paweł, 1948, Sedan, w: Sedan, Warszawa.

Hertz Paweł, 1948, Ucieczka z krainy Lambertów, w: Sedan, Warszawa.

Jadacki Jacek Juliusz, 2005, Analiza pojęcia melancholii, w: Lorenc I. (red.), Odłamki rozbitych luster. Rozprawy z filozofii, kultury, sztuki i estetyki ofiarowane Pani Profesor Alicji Kuczyńskiej, Warszawa.

Kania Agnieszka, 2015, „Polak mały” na lekcji o wielkich sprawach, czyli o patriotyzmie bez przesady, w: Janus-Sitarz A. i in. (red.), Trudne lekcje języka polskiego. Ku rozwiązaniom praktycznym, Kraków.

Kisielewski Stefan, 1947, Sprzysiężenie, Warszawa.

Klibansky Raymond, Panofsky Erwin, Saxl Fritz, 2009, Saturn i melancholia. Studia $z$ historii, filozofii, przyrody, medycyny, religii oraz sztuki, Kryczyńska A. (przeł.), Kraków.

Kopaliński Władysław, 1985, Słownik mitów i tradycji kultury, Warszawa.

Kopaliński Władysław, 1990, Słownik symboli, Warszawa.

Kwiek Marek, 2000, Melancholia - utopia - intelektualiści (czytając Wolfa Lepeniesa) na http://www.cpp.amu. edu.pl/pdf/wolf_lepenies.pdf (dostęp 15.06.2012).

Lepenies Wolf, 1997, Melancholia - próba legitymizacji zjawiska, Dybel P. (przeł.), „Studia Socjologiczne”, nr 1.

Najdek Kamilla, 2010, Cytat jako figura myśli. Z retoryki filozoficznej Hamanna i Benjamina, Nowa Wieś k. Torunia. 
Palska Hanna, 2008, Inteligencja twórcza w latach 1948-1956, w: Inteligencja w Polsce. Specjaliści, twórcy, klerkowie, klasa średnia?, Domański H. (red.), Warszawa.

Panofsky Erwin, 1971, Trzy ryciny Albrechta Dürera „Rycerz, Śmierć i Diabeł”, „Św. Hieronim w pracowni”, „Melancholia I”, w: Studia z historii sztuki, Ratkowska P. (przeł.), Białostocki J. (wybór i oprac.), Warszawa.

Sauerland Karol, 1986, O Bogu, języku, rzeczach i historii, w: Od Diltheya do Adorna. Studia z estetyki niemieckiej, Warszawa.

Simmel Georg, 2006, Ruina. Próba estetyczna, w: Most i drzwi. Wybór esejów, Łukasiewicz M. (przeł.), Warszawa.

Sobolewska Anna, 1979, Polska proza psychologiczna (1945-1950), Wrocław.

Sontag Susan, 1994, Pod znakiem Saturna, Kalaga W. (przeł.), „Res Publica Nowa", nr 6.

Starobinski Jean, 1996, Melancholia wśród ruin, M.L. (przeł.), „Zeszyty Literackie", nr 2.

Strawa-Kęsek Ewelina, 2015, Metoda projektu w edukacji polonistycznej, Kraków.

Vitale Augusto, 1987, Archetyp Saturna, czyli przemiana ojca, Prokopiuk J. (przeł.), „Pismo Literacko-Artystyczne”, nr 3.

Wyka Kazimierz, 1989, Rozrachunki inteligenckie, w: Pogranicze powieści, Warszawa.

Wysłouch Seweryna, 2011, Od socjologii do etyki. Wobec twórczości Kazimierza Brandysa, w: Wyprzedaż semiotyki, Brzóstowicz-Klajn M., Kaniewska B. (red.), Poznań.

Zaleski Marek, 1996, Formy pamięci. O przedstawianiu przeszłości w polskiej literaturze współczesnej, Warszawa.

Zaworska Helena, 1965, Po upadku mitów inteligenckich. O prozie tzw. obrachunków inteligenckich $w$ latach 1945-1948, w: Z problemów literatury polskiej XX wieku, Brodzka A., Żabicki Z. (red.), t. 3, Warszawa.

\section{O Autorce:}

Izabela Kozłowska - doktor nauk humanistycznych, jej zainteresowania badawcze dotyczą polskiej literatury powojennej, problematyki melancholijnej, metodyki nauczania literatury i języka polskiego. Autorka książki $W$ objęciach Saturna. Melancholia $w$ prozie rozrachunków inteligenckich (1946-1948). Publikowała m. in. w „Przestrzeniach Teorii”, „Kresach”, „Polonistyce”, "Języku Polskim w Liceum”. Polonistka i instruktorka szkolnego teatru. Adres e-mail: izabela1308@tlen.pl 
